\title{
Valorization of rice straw waste: production of porcelain tiles
}

\section{(Valorização de resíduos de palha de arroz: produção de porcelanatos)}

\author{
Álvaro Guzmán $A^{1 *}$, Silvio Delvasto $A^{1}$, Maria Francisca Quereda $V^{2}$, Enrique Sánchez $V^{2}$ \\ ${ }^{1}$ Composite Materials Group (Grupo de Materiales Compuestos), GMC. Escuela de Ingeniería de Materiales, \\ Facultad de Ingeniería, Universidad del Valle, Cali, Colombia. Calle 13 \# 100 - 00, Edif. 349 \\ ${ }^{2}$ Instituto de Tecnología Cerámica, ITC. Universidad Jaume I, Castellón, Spain. Campus Universitario Riu Sec \\ [James I University, Castellón, Spain. Campus Riu Sec], Av. Vicent Sos Baynat s/n, 12006 Castellón. \\ *alvaro8308@hotmail.com.co,silvio.delvasto@correounivalle.edu.co,paqui.quereda@itc.uji.es, \\ enrique.sanchez@itc.uji.es
}

\begin{abstract}
The rice industry generates huge amounts of rice straw ashes (RSA). This paper presents the results of an experimental research work about the incorporation of RSA waste as a new alternative raw material for production of porcelain tiles. The RSA replaces, partially or completely, the non-plastic raw materials (quartz (feldspathic sand in this research) and feldspar), that together with the clays, constitute the major constituents of formulations of porcelain tiles. A standard industrial composition ( $0 \%$ RSA) and two more compositions in which feldspar and feldspathic sand were replaced with two percentages of RSA ( $12.5 \%$ RSA and $60 \%$ RSA) were formulated, keeping the clay content constant. The mixtures were processed, reproducing industrial porcelain tile manufacturing conditions by the dry route and fired at peak temperatures varying from $1140-1260{ }^{\circ} \mathrm{C}$. The results showed that additions of $12.5 \% \mathrm{RSA}$ in replacement of feldspar and feldspathic sand allowed producing porcelain tiles that did not display marked changes in processing behaviour, in addition to obtain a microstructure and the typical mineralogical phases of porcelain tile. Thus, an alternative use of an agricultural waste material is proposed, which can be translated into economic and environmental benefits.
\end{abstract}

Keywords: porcelain tile, rice straw ash, feldspar, feldspathic sand.

\section{Resumo}

A indústria do arroz gera enormes quantidades de cinzas de palha de arroz (RSA). Este artigo apresenta os resultados de um trabalho de pesquisa experimental sobre a incorporação de resíduos RSA como uma nova matéria-prima alternativa para a produção de porcelanato. A RSA substitui, total ou parcialmente, as matérias-primas não-plásticas (quartzo (areia feldspática nesta pesquisa) e feldspato), que, juntamente com as argilas, constituem os principais componentes de formulações de porcelanato. A composição padrão industrial ( $(0 \%$ RSA) e mais duas composições em que feldspato e areia feldspática foram substituídos por duas porcentagens de RSA (12,5\% e 60\% RSA RSA) foram formuladas, mantendo a argila constante. As misturas foram processadas, reproduzindo porcelanato nas condições de produção industrial por via seca e queimas em temperaturas máximas variando entre $1140-1260{ }^{\circ} \mathrm{C}$. Os resultados mostraram que adições de $12,5 \%$ RSA em substituição da areia feldspato e feldspático permitiram produzir porcelanato que não mostraram mudanças marcantes no comportamento do processamento, além de obter uma microestrutura e as fases mineralógicas típicas de porcelanato. Assim, é proposta uma alternativa de uso de um material de resíduos agrícolas, o que pode ser traduzido em beneficios econômicos e ambientais.

Palavras-chave: azulejos de porcelana, arroz cinza palha, areia feldspato, feldspática.

\section{INTRODUCTION}

Porcelain stoneware tile is a ceramic product characterised by low water absorption $(\leq 0.5 \%$ according to the standard ISO 13006 [1]), making it a high-performance material [2]. Porcelain tile is typically used in flooring, wall cladding, and ventilated façades [3]. In recent years, porcelain tile production and sales have grown, compared withproduction and sales rates of other ceramic construction materials, as a result of its high technological properties, particularly in regard to water absorption and frost resistance, and mechanical properties, such as modulus of ruptureand abrasionresistance [2-5].

A typical porcelain tile composition consists of $40-50 \%$ illitic-kaolinitic clay, $10-15 \%$ quartz, and 35\%-45\% feldspar (all percentages by weight) [6,7]. Feldspar is a high-cost raw material and replacement would represent a significant reduction in porcelain tile production costs $[8,9]$. Feldspar is a mineralflux commonly used in porcelain tile bodies. 
However, high-grade feldspathic minerals resources have recently begun to become scarce, thus making it necessary to consider alternative sources of fluxing materials that can form glassy phase at temperatures equal toor lower than those of the feldspars used at present [10]. It should be added that deposits of good quality quartz sand in Colombia are limited. As a result, various alternative fluxes (soda-lime glasses, glass scrap (TV/PC cathode ray tubes and screens), blast furnace slag, metallurgical slags, zeolites, rice straw ash (RSA), etc.) and non-plastic materials (rice husk ash(RHA), silica fume (SF), fly ash (FA)) have been incorporated intoporcelain tile body compositions, with a view to studying their effecton product firing behaviour and end-product technical properties [10-24]. However, the use of secondary raw materials is considered feasible only if the industrial process remains essentially unaltered and product quality and properties are not impaired $[13,19]$.

As feldspars generally come from just a few regions, e.g. Germany, Turkey, and France, in addition to the limited deposits of good quality quartz sands in Colombia, their possible replacement with rice straw ash (RSA) is an attractive option, taking into account the results of Guzmán et al. [24] and the $\mathrm{K}_{2} \mathrm{O}$ and $\mathrm{SiO}_{2}$ contained in $\mathrm{RSA}$, which is of the order of $11.30-12.30 \%$ and $74.31-74.67 \%$ by weight of the ash, respectively $[25,26]$.

This study was undertaken to examine the feasibility of using rice straw ash (RSA) in ceramic mixtures topartially replacenon-plastic materials (sodium feldspar and feldspathic sand) used in manufacturing porcelain tilebodies. The effects due to the use of RSA were investigated in laboratory experiments and discussed in terms of firing behaviour and physical-mechanical properties.

\section{EXPERIMENTAL PROCEDURE}

\section{Materials}

The raw materials used in preparing triaxial ceramic

Table I - Chemical and mineralogical compositions of the raw materials.

[Tabela I - Composições químicas e mineralógicas das matérias-primas.]

\begin{tabular}{|c|c|c|c|c|}
\hline \multirow{2}{*}{$\begin{array}{l}\text { Element and/or } \\
\text { compound }\end{array}$} & \multicolumn{4}{|c|}{ Concentration by weight (\%) } \\
\hline & $\begin{array}{l}\text { Illitic-kaolinitic clay } \\
\text { (A) }\end{array}$ & Sodium feldspar (F) & $\begin{array}{l}\text { Feldspathic sand } \\
\qquad(\mathrm{AF})\end{array}$ & $\begin{array}{l}\text { RSA } \\
\text { (C) }\end{array}$ \\
\hline $\mathrm{SiO}_{2}$ & 59.00 & 70.00 & 91.00 & 79.62 \\
\hline $\mathrm{Al}_{2} \mathrm{O}_{3}$ & 27.30 & 18.00 & 5.00 & 0.27 \\
\hline $\mathrm{Fe}_{2} \mathrm{O}_{3}$ & 0.93 & 0.08 & 0.12 & 0.26 \\
\hline $\mathrm{CaO}$ & 0.27 & 0.50 & 0.10 & 2.80 \\
\hline $\mathrm{MgO}$ & 0.59 & 0.10 & 0.01 & 0.89 \\
\hline $\mathrm{Na}_{2} \mathrm{O}$ & 0.52 & 9.70 & 0.10 & 0.35 \\
\hline $\mathrm{K}_{2} \mathrm{O}$ & 2.45 & 0.35 & 2.50 & 10.53 \\
\hline $\mathrm{TiO}_{2}$ & 1.45 & 0.11 & 0.08 & - \\
\hline $\mathrm{MnO}$ & $<0.01$ & - & - & 0.71 \\
\hline $\mathrm{P}_{2} \mathrm{O}_{5}$ & 0.05 & - & - & 1.61 \\
\hline $\mathrm{Cl}$ & - & - & - & 0.59 \\
\hline$S$ & - & - & - & 1.74 \\
\hline$Z n$ & - & - & - & 0.01 \\
\hline$R b$ & - & - & - & 0.01 \\
\hline$S r$ & - & - & - & 0.01 \\
\hline $\mathrm{Cu}$ & - & - & - & 0.01 \\
\hline LOI & 7.29 & 0.50 & 1.10 & 0.59 \\
\hline \multirow{4}{*}{$\begin{array}{l}\text { Mineralogical } \\
\text { phases }\end{array}$} & $\begin{array}{c}\text { Kaolinite (ICSD } \\
87771 \text { ) }\end{array}$ & $\begin{array}{c}\text { Albite (ICSD } \\
\text { 90142) }\end{array}$ & $\begin{array}{c}\text { Quartz (ICSD } \\
83849 \text { ) }\end{array}$ & $\begin{array}{c}\text { Cristobalite } \alpha \text { (ICSD } \\
74530)\end{array}$ \\
\hline & $\begin{array}{l}\text { Muscovite (ICSD } \\
\text { 202263) }\end{array}$ & $\begin{array}{l}\text { Muscovite (ICSD } \\
\text { 25803) }\end{array}$ & $\begin{array}{l}\text { Kaolinite (ICSD } \\
\text { 87771) }\end{array}$ & $\begin{array}{c}\text { Tridymite } \alpha(\text { ICSD } \\
1109)\end{array}$ \\
\hline & Quartz (ICSD 90145) & $\begin{array}{c}\text { Quartz (ICSD } \\
34636)\end{array}$ & $\begin{array}{c}\text { Orthoclase (ICSD } \\
159347)\end{array}$ & \\
\hline & Anatase (ICSD 96946) & & & \\
\hline
\end{tabular}


bodies were feldspathic sand, sodium feldspar, and illitickaolinitic clay. To obtainthe RSA, amethodology was usedfor the obtainment of RSA by a calcination process of the materialat $800^{\circ} \mathrm{C}$ to eliminate chlorine and sulphuras far as possiblewith a moderate content of potassium in the ash [24]. After the RSA had been obtained, it was subjected to milling for one hour in a laboratory ball mill. The chemical and mineralogical compositions of the raw materials were determined by X-ray fluorescence and X-ray diffraction, respectively (see Table I). The mineralogical phases are reported with the Inorganic Crystal Structure Database (ICSD) patterns corresponding to the identified minerals.

The chemical composition, determined by XRF, of the RSA obtained by calcination at $800^{\circ} \mathrm{C}$ showed that the main constituents were $\mathrm{SiO}_{2}$ and $\mathrm{K}_{2} \mathrm{O}$ (see Table I), corroborating the results reported by Jenkins et al. [25] and Thy et al. [26]. With relation to the clay, this consisted mainly of $\mathrm{SiO}_{2}$ and $\mathrm{Al}_{2} \mathrm{O}_{3}$. In addition, it displayed low contents of $\mathrm{K}_{2} \mathrm{O}$ and $\mathrm{TiO}_{2}$ ( $2.5 \%$ and $1.5 \%$, respectively), in which the $\mathrm{K}_{2} \mathrm{O}$ could act as a flux, while $\mathrm{TiO}_{2}$ was a chromophore oxide that provided a yellowish hue [27]. The feldspar, in turn, consisted mainly of $\mathrm{SiO}_{2}$ and $\mathrm{Al}_{2} \mathrm{O}_{3}$, as well as $9.7 \% \mathrm{Na}_{2} \mathrm{O}$, indicating that it was a sodium feldspar. On the other hand, the feldspathic sand mainly contained $\mathrm{SiO}_{2}$ and $\mathrm{Al}_{2} \mathrm{O}_{3}$, in addition to $2.5 \% \mathrm{~K}_{2} \mathrm{O}$, which could act as a flux.

\section{Ceramics formulation and testing}

A standard industrial composition labelled 0\% RSA, and two more compositions labelled $12.5 \%$ RSA and $60 \%$ RSA in which feldspar and feldspathic sand were replaced with two percentages of RSA (12.5 wt.\% and 60 wt.\%, respectively) were formulated, keeping the clay content constant in all formulations. The chemical compositions of the corresponding porcelain are reported in Table II.

The replacement of feldspar and feldspathic sand with RSA in the mixture, in general, led to an increase in the $\mathrm{SiO}_{2}$, $\mathrm{K} 2 \mathrm{O}, \mathrm{MgO}, \mathrm{CaO}, \mathrm{Fe}_{2} \mathrm{O}_{3}$ and $\mathrm{Cl}$ contents, in addition to a reduction in the $\mathrm{Al}_{2} \mathrm{O}_{3}$ and $\mathrm{Na}_{2} \mathrm{O}$ contents (Table II). Thus, the expected behaviour of compositions is, in some extent, unpredictable due to these compositional changes.

In order to obtain the typical particle size of porcelain tile body compositions, one $\mathrm{kg}$ of each ceramic formulation wasball-milled to a residue (R) of $1.5-2.0 \%$ on a $40 \mu \mathrm{m}$ sieve. Table III details the dry milling times required to prepare the formulations to a residue of $1.5-2.0 \%$ on a $40 \mu \mathrm{m}$ sieve. As observed, the higher the RSA content the shorter is the milling time.

In order to determine the behaviour of the ceramic bodies in pressing and firing, cylindrical test pieces about $7 \mathrm{~mm}$ thick and $40 \mathrm{~mm}$ in diameter, in addition toprism-shaped test pieces measuring $80 \times 20 \times 6 \mathrm{~mm}$, were prepared to determine the mechanical properties. The test pieces were formed at a moisture contentof $5.5 \mathrm{wt} . \%$ (on a dry basis) by uniaxial pressing at a pressure of $400 \mathrm{~kg} / \mathrm{cm}^{2}$. After they had been pressed, the test pieces were dried at $110 \pm 5^{\circ} \mathrm{C}$ in an electric laboratory oven. They were then sintered in a Pirometrol $\mathrm{R}$
Table II - Chemical composition (wt.\%) of porcelain samples as formulated.

[Tabela II - Composição química (peso\%) das amostras de porcelana, como formulado.]

\begin{tabular}{cccc}
\hline $\begin{array}{c}\text { Element } \\
\text { and/or } \\
\text { compound }\end{array}$ & \multicolumn{3}{c}{ Concentration by weight (\%) } \\
\hline $\mathrm{SiO}_{2}$ & 67.70 & 67.85 & 71.37 \\
$\mathrm{Al}_{2} \mathrm{O}_{3}$ & 20.42 & 18.85 & 11.08 \\
$\mathrm{Fe}_{2} \mathrm{O}_{3}$ & 0.42 & 0.44 & 0.53 \\
$\mathrm{CaO}$ & 0.37 & 0.68 & 1.79 \\
$\mathrm{MgO}$ & 0.29 & 0.39 & 0.77 \\
$\mathrm{Na}_{2} \mathrm{O}$ & 5.07 & 4.38 & 0.42 \\
$\mathrm{~K}_{2} \mathrm{O}$ & 1.41 & 2.57 & 7.30 \\
$\mathrm{TiO}_{2}$ & 0.64 & 0.63 & 0.58 \\
$\mathrm{MnO}$ & 0.00 & 0.09 & 0.43 \\
$\mathrm{P}_{2} \mathrm{O}_{5}$ & 0.02 & 0.22 & 0.99 \\
$\mathrm{Cl}$ & 0.00 & 0.07 & 0.35 \\
$\mathrm{~S}$ & 0.00 & 0.22 & 1.04 \\
$\mathrm{Zn}$ & 0.00 & 0.00 & 0.01 \\
$\mathrm{Rb}$ & 0.00 & 0.00 & 0.01 \\
$\mathrm{Sr}$ & 0.00 & 0.00 & 0.01 \\
$\mathrm{Cu}$ & 0.00 & 0.00 & 0.01 \\
\hline
\end{tabular}

Table III - Milling time required to reach a residue of 1.5$2.0 \%$ on a $40 \mu \mathrm{m}$ sieve.

[Tabela III - Tempo de moagem necessário para atingir um resíduo de 1,5-2,0\% em peneira de $40 \mu \mathrm{m}$.

\begin{tabular}{ccc}
\hline Mixture & $\mathrm{t}(\mathrm{min})$ & $\% \mathrm{R}(40 \mu \mathrm{m})$ \\
\hline 0\% RSA (10AF;50F;0C;40A) & 50 & 2,2 \\
12.5\% RSA (5AF;42.5F;12.5C;40A) & 25 & 2,0 \\
60\% RSA (0AF;0F;60C;40A) & 17 & 1,6 \\
\hline
\end{tabular}

electric laboratory kiln with a heating ramp of $70{ }^{\circ} \mathrm{C} / \mathrm{min}$ between $25{ }^{\circ} \mathrm{C}$ and $500{ }^{\circ} \mathrm{C}$, and $25^{\circ} \mathrm{C} / \mathrm{min}$ from $500{ }^{\circ} \mathrm{C}$ to the respective peak firing temperature. The residence time at peak firing temperature was $6 \mathrm{~min}$, and the fired test pieces were cooled inside the kiln in order to avoid macroscopic residual stresses. The peak firing temperatures encompassed the range $1140-1260{ }^{\circ} \mathrm{C}$, at intervals of $20^{\circ} \mathrm{C}$, depending on each composition. The measurements of dried and fired dimensions of the test pieces were made using a digital calliper.

The maximum densification temperature was determined for each mixture from the vitrification curve, constructed after determining the bulk density, using the experimental conditions described previously. Owing to the scarce variation of water absorption with temperature at values below $1 \%$, it was preferable to determine the maximum densification 
temperature as the characteristic temperature for industrial firing temperatures instead of the temperature at which the water absorption was less than $0.5 \%$.

The technological properties of the fired test pieces were evaluated by performing the following tests: linear shrinkage, apparent porosity, water absorption, and bulk density. The linear shrinkage, LS (\%), of fired samples was determined according to the Standard Test Method for Drying and Firing Shrinkages of Ceramic Whiteware Clays [28] by means of the following equation:

$$
L_{S}=\frac{L_{d}-L_{f}}{L_{d}} \times 100
$$

being $\mathrm{L}_{\mathrm{d}}$ and $\mathrm{L}_{\mathrm{f}}$ the diameter $(\mathrm{mm})$ of dried and fired samples, respectively.

The bulk densities, $\mathrm{BD}\left(\mathrm{g} / \mathrm{cm}^{3}\right)$, ofdried $\left(\mathrm{BD}_{\mathrm{d}}\right)$ and fired $\left(\mathrm{BD}_{\mathrm{f}}\right)$ samples were determined by the mercury displacement method measured by means of the following equation:

$$
\mathrm{BD}=\frac{\mathrm{m}_{\mathrm{x}} \mathrm{x}-\rho_{\mathrm{Hg}}}{\mathrm{m}_{\mathrm{Hg}}} \times 100
$$

being $m_{x}$ the mass of dried $\left(m_{d}\right)$ or fired sample $\left(m_{f}\right), \rho_{\mathrm{Hg}}$ the density of mercury $\left(13.53 \mathrm{~g} / \mathrm{cm}^{3}\right)$ and $\mathrm{m}_{\mathrm{Hg}}$ the mass of each sample submerged in mercury [29].

The water absorption, WA (\%),was measured according to the Standard Test Method for Water Absorption, Bulk Density, Apparent Porosity, and Apparent Specific Gravity of Fired Whiteware Products [30], which involves drying the test specimens to constant mass (D), boiling in distilled water for $5 \mathrm{~h}$ and soak for an additional $24 \mathrm{~h}$ at room temperature. After impregnation, the saturated mass (M) of each specimen is determined. WA expresses the relationship of the mass of water absorbed to the mass of the dry specimen as follows:

$$
\mathrm{WA}=\frac{\mathrm{M}-\mathrm{D}}{\mathrm{D}} \times 100
$$

The apparent porosity, $\varepsilon_{\alpha}(\%)$, expresses the relationship of the volume of open pores to the exterior volume of the specimen and is calculated as follows:

$$
\varepsilon_{\mathrm{a}}=\mathrm{BD}_{\mathrm{f}} \mathrm{xWA}
$$

The modulus of rupture was determined analogously to the Standard Test Methods for Flexural Properties of Ceramic Whiteware Materials [31] by a three-point bending test assembly, the span between supports being $62.2 \mathrm{~mm}$ and the load application rate being $5 \mathrm{~mm} / \mathrm{min}$. An average of ten measurements was taken for this purpose. In the STD mixture $(0 \%$ RSA $)$ and the mixture with RSA in replacement of feldspar that exhibited the best modulus of rupture $(12.5 \%$ RSA), the main crystalline phases were identified by XRD using a PANalytical X'Pert PRO X-ray diffractometer. The microstructural characteristics were observed by scanning electron microscopy, for which the fracture surface of each sample was polished and attacked with a hydrofluoric acid (HF) solution at $5 \%$ for $3 \mathrm{~min}$, washed with distilled water and ethyl alcohol, and subsequently dried and coated with carbon.

\section{RESULTS AND DISCUSSION}

Feasibilityof using RSA as a non-plastic material in porcelain tile compositions

The vitrification curves of the mixtures $0 \%$ RSA, $12.5 \%$ RSA and $60 \%$ RSA are plotted in Fig. 1. Regarding optimum firing range (interval of temperatures where water absorption is lower than $0.5 \%$ and bulk density is maximized), it can be observed that $12.5 \%$ RSA composition showed a similar temperature range than $0 \%$ RSA. Moreover, the $60 \%$ RSA composition showed a shorter temperature range than $0 \%$ RSA; this indicates that more careful control is required during the firing process of this porcelain. From the vitrification curves, the optimum firing temperatures (those corresponding to maximum density) for each composition were determined to be $1183{ }^{\circ} \mathrm{C}, 1183{ }^{\circ} \mathrm{C}$, and $1234{ }^{\circ} \mathrm{C}$, respectively.

The results of the technical properties obtained for each dried as well as fired composition, at its respective optimum firing temperature, are detailed in Table IV.

The increase in the quantity of RSA in the mixture decreased the compactness of the test piece, evidenced by a reduction in dry bulk density. This behaviour could stem from the fact that it adversely affected the balance between the non-plasticand the colloidal plastic particles, raising the linear shrinkage of the fired test pieces. Compositions $12.5 \%$ RSA and $60 \%$ RSA displayed this behaviour, with an increase in linear shrinkage in comparison with standard mixture $0 \%$ RSA ( $8.1 \%$ ). The optimum vitrification range is achieved when apparent porosity reaches a minimum value, tending to be nearly zero and simultaneously bulk density and linear shrinkage are maxims. Firing above the vitrification range has a drastic adverse effect on the physical properties owing to an increase in the pressure of the gases trapped in the pores, producing swelling or bloating of the piece [4]. The maximum bulk densityof each composition decreased as the replacementof feldspar and feldspathic sandwith RSA increased, in comparison with that of standard mixture $0 \%$ RSA, as a result of the lowerdry bulk density of the compositions with RSA. Mixture $12.5 \%$ RSA exhibited the highest bulk density $\left(2.36 \mathrm{~g} / \mathrm{cm}^{3}\right)$ with respect to the other mixture with RSA. Thus, mixture $60 \%$ RSA displayed a reduction in bulk density $\left(2.12 \mathrm{~g} / \mathrm{cm}^{3}\right)$ to the extent of being lower than the minimum value of $2.30 \mathrm{~g} / \mathrm{cm}^{3}$ specified by the European standard UNI EN 87 [32].

The apparent porosity and water absorption percentage of mixture $12.5 \%$ RSA displayed similar trend to those of standardmixture 0\% RSA. However, mixture $60 \%$ RSA exhibited higher values, which could be attributed to different factors, such as their low dry bulk density and 

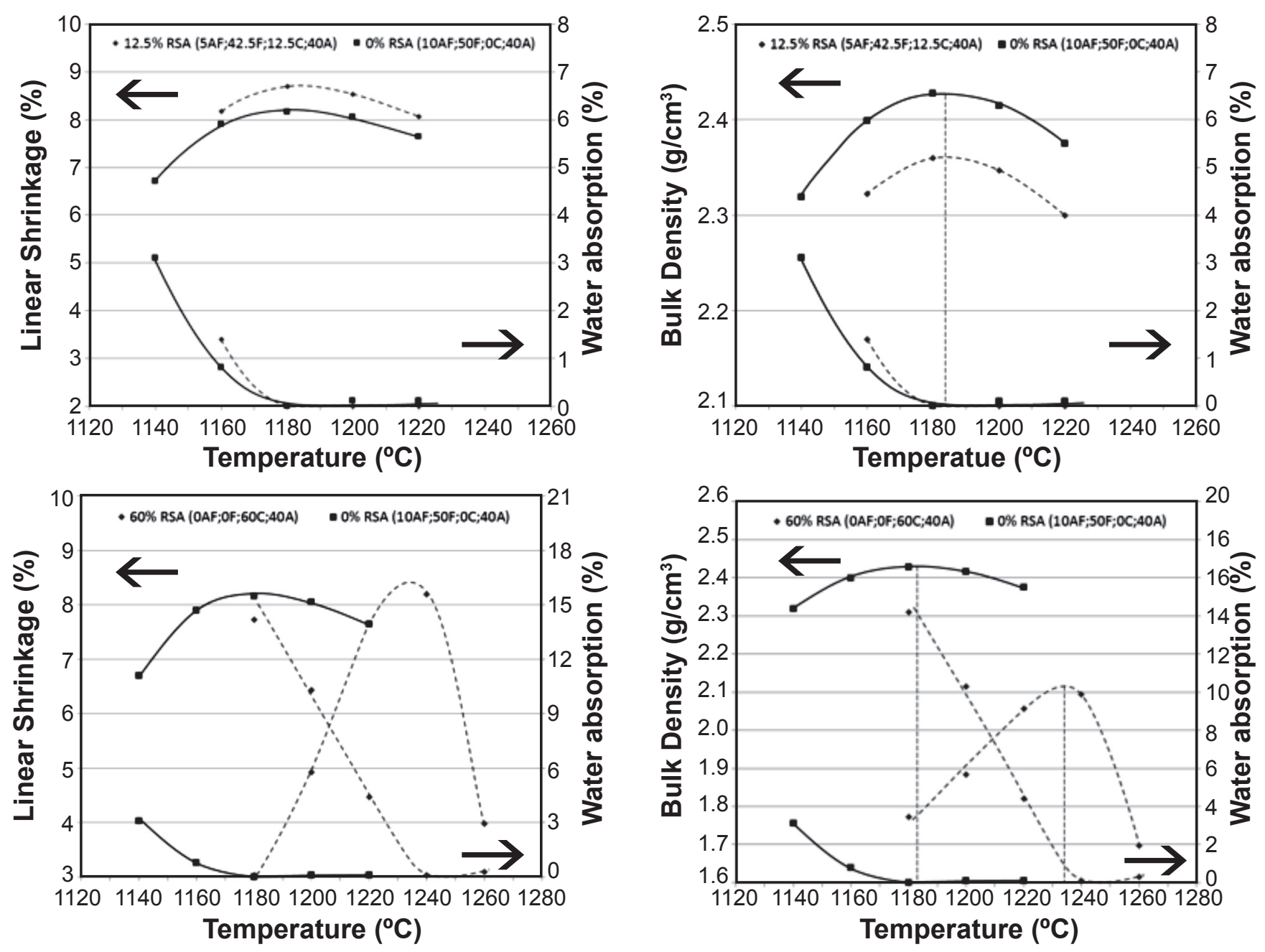

Figure 1: Linear shrinkage, water absorption and bulk density in the porcelain tile samples (0\% RSA, $12.5 \%$ RSA and $60 \%$ RSA) as a function of firing temperature. $0 \%$ RSA appears in all the plots as a standard composition.

[Figura 1: Retração linear, absorção de água e densidade aparente das amostras de azulejos de porcelana (0\% de RSA, 12,5\% e 60\% de RSA RSA) como uma função da temperatura de queima. $0 \%$ RSA aparece em todas as parcelas, como uma composição padrão.]

the bloating caused by the greater content ingas-generating substances $\left(\mathrm{Fe}_{2} \mathrm{O}_{3}, \mathrm{Cl}\right.$, andLOI) in the $\mathrm{RSA}$, in addition to the increase in the quantity of $\mathrm{SiO}_{2}$, which reduced the sintering capacity, and the increase in the quantity of liquid phase of potassium origin, increasing its viscosity in comparison with that of the liquid phase of sodium originin agreement with the findings previously reported $[7,33]$. These phenomena were corroborated by the decrease in shrinkage and increase in porosity displayed by mixture $60 \%$ RSA (see Table IV), typical behaviourof the bloating phenomenon during liquidphase sintering of traditional ceramics [4].

The modulus of ruptureof the fired test pieces (see Table IV) evidences a similar trend to that displayed by fired bulk density. The previous phenomena are consistent with reported findings [8], who noted that generally, at greater bulk density, the modulus of rupture increased as a consequence of reduction of porosity. According to the criteria of standard IS0 13006 for dry-pressed ceramic tiles, ceramic tile is defined as porcelain stoneware tile belonging to group BIa, when it exhibits a modulus of rupture $\leq 35 \mathrm{MPa}$ and water absorption $\leq 0.5 \%$. In view of the results of the modulus of ruptureand water absorption (see Table IV), compositions

Table IV - Physical and mechanical properties of the dried and fired test pieces obtained at their optimum firing temperature.

[Tabela IV - Propriedades físicas e mecânicas das peças obtidas via seca e tratadas a temperatura ótima de queima.]

\begin{tabular}{lccc}
\hline \multicolumn{1}{c}{ Technical properties } & $0 \%$ & $12.5 \%$ & $60 \%$ \\
& RSA & RSA & RSA \\
\hline Dry bulk density $\left(\mathrm{g} / \mathrm{cm}^{3}\right)$ & 1.91 & 1.83 & 1.65 \\
Optimum firing temperature $\left({ }^{\circ} \mathrm{C}\right)$ & 1,183 & 1,183 & 1,234 \\
Linear shrinkage $(\%)$ & 8.1 & 8.7 & 8.6 \\
Fired bulk density $\left(\mathrm{g} / \mathrm{cm}^{3}\right)$ & 2.43 & 2,36 & 2.12 \\
Water absorption $(\%)$ & $<0.1$ & $<0.1$ & 0.2 \\
Apparent porosity $(\%)$ & $<0.1$ & $<0.1$ & 0.5 \\
Modulus of rupture $(\mathrm{MPa})$ & 69 & 67 & 48 \\
\hline
\end{tabular}



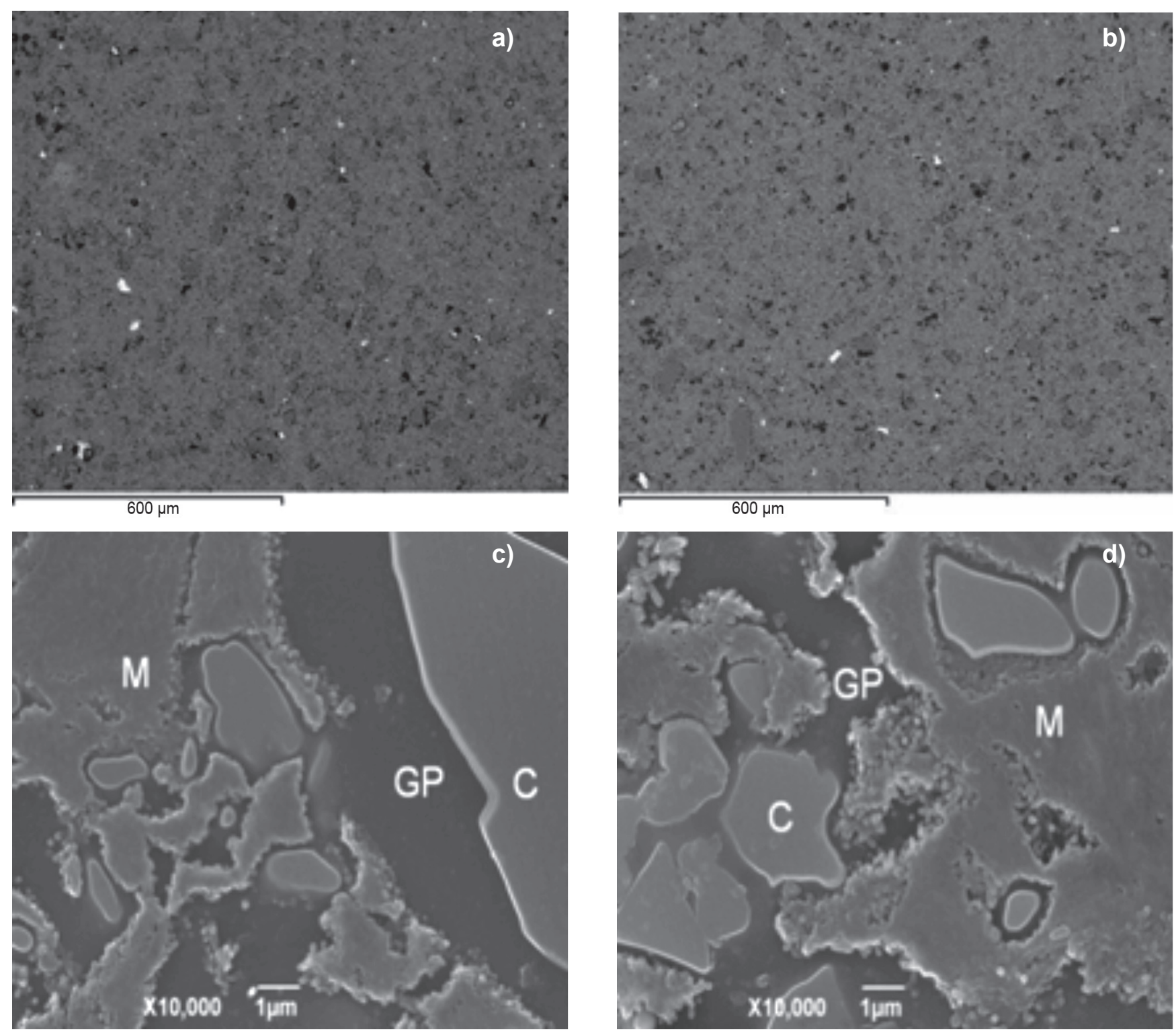

Figure 2: SEM micrographs in BSE (backscattered electron) mode of polished surfaces of fired test pieces $0 \%$ RSA (a) and $12.5 \%$ RSA (b) (100X); and SEM micrographs in SEI (secondary electron imaging) mode of polished surfaces of fired test pieces $0 \%$ RSA (c) and $12.5 \%$ RSA (d) (10000X).

[Figura 2: Micrografias obtidas em mivroscópio eletrônico de varredura em BSE (elétrons retroespalhados) de superficies polidas das peças queimadas com 0\% RSA (a) e 12,5\% RSA (b) (100X); e micrografias em SEI (imagem de elétron secundária) de superfícies polidas das peças queimadas com $0 \%$ RSA (c) e 12,5\% RSA (d) (10000x).]

$0 \%$ RSA, $12.5 \%$ RSA and $60 \%$ RSA could all be deemedas porcelain stoneware tile belonging to group BIa. However, in composition $60 \%$ RSA, there must also bean increase in the optimum firing temperature. In addition, the optimum firing range was very narrow (see Fig. 1), reducing the feasibility of using these mixture on an industrial scale.

The SEM micrographs at 100X in backscattered electron mode of the polished surfaces (see Figs. $2 \mathrm{a}$ and $2 \mathrm{~b}$ ) showed that the surface of the test piece fired under maximum densification conditions of composition $12.5 \%$ RSA displayed a greater quantity of closed pores than the test piece of composition $0 \%$ RSA; which was consistent with the density and porosity values noted previously.

The SEM micrographs at $10000 \mathrm{X}$ in secondary electron imaging (SEI) mode (see Figs. 2c and 2d) showed the presence of primary mullite crystals $(\mathrm{M})$ and quartz crystals (C) embedded in a glassy phase (GP) in the microstructure of fired test pieces of compositions 0\% RSA and 12.5\% RSA. The SEM results were corroborated by XRD tests of fired test pieces of compositions 0\% RSA and 12.5\% RSA (see Fig. $3)$, highlighting the presence of $\alpha$-quartz $\left(2 \theta=20.86^{\circ}\right.$ and $\left.26.64^{\circ}\right)(\operatorname{ICSD} 83849)$, albite $\left(2 \theta=22.03^{\circ}\right.$ and $\left.27.91^{\circ}\right)(\mathrm{ICSD}$ $240519)$, and mullite $\left(2 \theta=16.43^{\circ} ; 33.21^{\circ} ; 35.26^{\circ} ; 39.24^{\circ}\right.$, and $40.87^{\circ}$ ) (ICSD 99328), this last phase being partially responsible for porcelain mechanical strength. In addition, in $12.5 \% \mathrm{RSA}$ the presence of $\alpha$-cristobalite was evidenced $\left(2 \theta=21.76^{\circ}\right)($ ICSD 74530$)$, basically stemming from the RSA (see Table I) in agreement with reported findings [34]. 


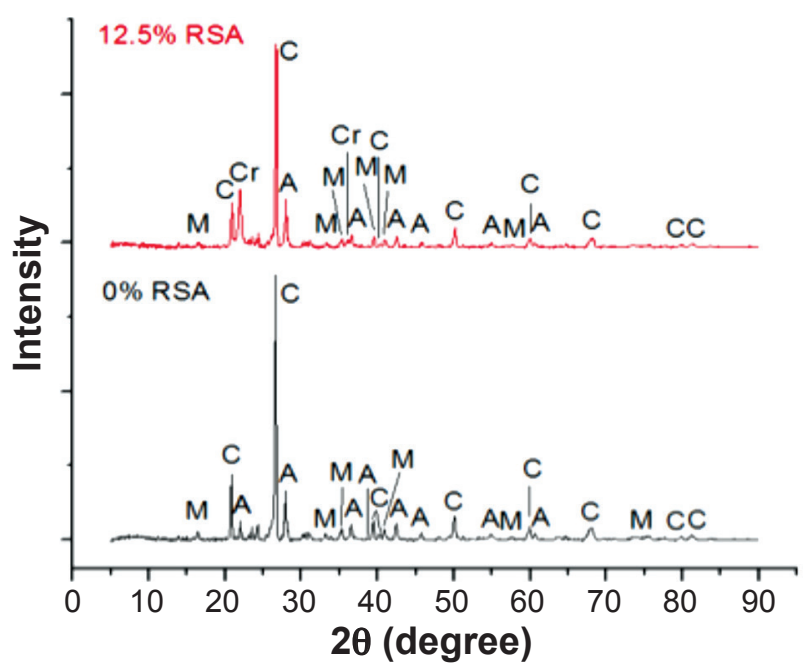

Figure 3: X-ray diffraction patterns: $0 \%$ RSA (a) and 12.5\% RSA (b) $(\mathrm{M}=$ mullite, $\mathrm{C}=$ quartz, $\mathrm{Cr}=$ cristobalite, $\mathrm{A}=$ albite $)$.

[Figura 3: Difração de raios X: 0\% de RSA (a) e 12,5\% de RSA (b) $(M=$ mulita,$C=$ quartzo, $C r=$ cristobalita, $A=$ albita $)$.

\section{CONCLUSIONS}

Rice straw ashes (RSA) displayed anon-plastic character, allowing them to be used as partial replacement of feldspar and quartz in porcelain tile compositions. No pronounced change took place in the technological process when RSA was added to the composition in a quantity of $12.5 \%$, in replacement of feldspar and feldspathic sand, allowing the obtaining of mineralogical phases and microstructure of typical porcelain tiles.The fired test pieces of all the compositions studied with a RSA addition (12.5\% RSA and $60 \%$ RSA) exhibited the characteristics required for porcelain stoneware tile, BIa group (modulus of rupture $\geq$ $35 \mathrm{MPa}$ and water absorption $\leq 0.5 \%$ ) according to standard ISO 13006. However, in the composition in which RSA completely replaced feldspathic sand and feldspar, $60 \%$ RSA, the optimum firing range was narrower, in addition to requiring higher firing temperatures. This reduces the feasibilityof using this last mixtureon an industrial scale.

\section{ACKNOWLEDGEMENTS}

The authors would like to thank Universidad del Valle (Colombia), Instituto de Tecnología Cerámica(ITC) (España) and COLCIENCIAS (Colombia) for their support provided to conduct this study. In particular, this paper presents the partial results from the research project "Triaxial ceramics based on rice straw ash", code 110652128358, supported by COLCIENCIAS, Official Call 521 of 2010, contract RC. No. 325-2011.

\section{REFERENCES}

[1] ISO 13006:1998,“Ceramic tiles - Definitions, classification, characteristics and marking. International
Organization for Standardization" (1998).

[2] E. Sánchez, M.J. Ibáñez, J. García-Ten, M.F. Quereda, I.M. Hutchings, Y.M. Xu, "Porcelain tile microstructure: Implications for polished tile properties", J. Eur. Ceram. Soc. 26 (2006) 2533-2540.

[3] C. Zanelli, M. Raimondo, G. Guarini, M. Dondi, “The vitreous phase of porcelain stoneware: Composition, evolution during sintering and physical properties", J. NonCryst. Solid. 357 (2011) 3251-3260.

[4] J.M. Márquez, J.M. Rincón, M. Romero, "Effect of firing temperature on sintering of porcelain stoneware tiles", Ceram. Int. 34 (2008) 1867-1873.

[5] A. De Noni Jr, D. Hotza, V. Cantavella, E. Sánchez, "Analysis of the development of microscopic residual stresses on quartz particles in porcelain tile",J. Eur. Ceram. Soc. 28 (2008) 2629-2637.

[6] F. Andreola, L. Barbieri, A. Corradi, I. Lancellotti, T. Manfredini, "Utilisation of municipal incinerator grate slag for manufacturing porcelainized stoneware tiles manufacturing", J. Eur. Ceram. Soc. 22 (2002) 1457-1462.

[7] C. Zanelli, M. Raimondo, M. Dondi, G. Guarini, P.M. Tenorio, "Sintering mechanisms of porcelain stoneware tiles", In Qualicer 2004, Proc. VIII World Cong. Ceramic Tile Quality, Cámara Oficial de Comercio, Industria y Navegación, Castellón, Spain. papers C (2004) 247-259. (available at: <http://aulavirtual.camaracastellon.com/ qualicerCD/pdf/0413191e.pdf> [consulted on July 20, 2014]).

[8] S.R. Braganca, C.P. Bergmann, "Traditional and glass powder porcelain: technical and microstructure analysis", J. Eur. Ceram. Soc. 24 (2004)2383-2388.

[9] F. Andreola, L. Barbieri, E. Karamanova, I. Lancellotti, M. Pelino, "Recycling of CRT panel glass as fluxing agent in the porcelain stoneware tile production", Ceram. Int. 34 (2008) 1289-1295.

[10] K. Dana, S.K. Das, "Partial substitution of feldspar by B.F. slag in triaxial porcelain: Phase and microstructural evolution", J. Eur. Ceram. Soc. 24 (2004) 3833-3839.

[11] C.S. Prasad, K.N. Maiti, R. Venugopal, "Effect of rice husk ash in whiteware compositions", Ceram. Int. 27 (2001) 629-635.

[12] C.S. Prasad, K. N. Maiti, R. Venugopal,"Effect of silica fume addition on the properties of whiteware compositions", Ceram. Int. 28 (2002) 9-15.

[13] F. Matteucci, M. Dondi, G. Guarini, "Effect of sodalime glass on sintering and technological properties of porcelain stoneware tiles", Ceram. Int. 28 (2002) 873-880.

[14] R. De Gennaro, P. Cappelletti, G. Cerri, M. De Gennaro, M. Dondi, G. Guarini, A. Langella, D. Naimo, "Influence of zeolites on the sintering and technological properties of porcelain stoneware tiles", J. Eur. Ceram. Soc. 23 (2003) 2237-2245.

[15] K. Dana, S.K. Das, "High strength ceramic floor tile compositions containing Indian metallurgical slags",J. Mater. Sci. Lett. 22 (2003) 387-389.

[16] K. Dana, S.K. Das, "Evolution of microstructure in fly ash-containing porcelain body on heating at different 
temperatures”, Bull. Mater. Sci. 27 (2004b)183-188.

[17] K. Dana, S.K. Das, "Enhanced resistance to thermal cycling of slag-containing vitrified porcelain tiles", Industrial Ceramics 28 (2008) 121-124.

[18] K. Dana, S. Das, S.K. Das, "Effect of substitution of fly ash for quartz in triaxial kaolin-quartz-feldspar system", J. Eur. Ceram. Soc. 24 (2004) 3169-3175.

[19] A. Tucci, L. Esposito, E. Rastelli, C. Palmonari, E. Rambaldi, "Use of soda-lime scrap-glass as a fluxing agent in a porcelain stoneware tile mix", J. Eur. Ceram. Soc. 24 (2004) 83-92.

[20] K. Dana, J. Dey, S.K. Das, "Synergistic effect of fly ash and blast furnace slag on the mechanical strength of traditional porcelain tiles", Ceram. Int. 31 (2005) 147-152.

[21] R. De Gennaro, M. Dondi, P. Cappelletti, G. Cerri, M. De Gennaro, G. Guarini, A. Langella, L. Parlato, C. Zanelli, "Zeolite-feldspar epiclastic rocks as flux in ceramic tile manufacturing, Microporous", Mesoporous Mater. 105 (2007) 273-278.

[22] M. Raimondo, C. Zanelli, F. Matteucci, G. Guarini, M. Dondi, J.A. Labrincha, "Effect of waste glass (TV/PC cathodic tube and screen) on technological properties and sintering behaviour of porcelain stoneware tiles", Ceram. Int. 33 (2007) 615-623.

[23] A.S. Demirkiran, E. Artir, E. Avci, "Effect of natural zeolite addition on sintering kinetics of porcelain bodies", J. Mater. Process. Technol. 203 (2008) 465-470.

[24] A. Guzmán, S. Delvasto, E. Sánchez, V. Amigó, "Cenizas del tamo de arroz como substituto del feldespato en la fabricación de cerámica blanca", Boletín de la Sociedad Española de Cerámica y Vidrio 52 (2013) 25-30.

[25] B.M. Jenkins, L.L. Baxter, T.R. Miles Jr, T.R. Miles, "Combustion properties of biomass", Fuel. Process. Technol. 54 (1998) 17-46.

[26] P. Thy, B.M. Jenkins, S. Grundvig, R. Shiraki, C.E.
Lesher, "High temperature elemental losses and mineralogical changes in common biomass ashes", Fuel. 85 (2006) 783-795.

[27] A. Barba, V. Beltrán, C. Felíu, J. García, F. Ginés, E. Sánchez, V. Sanz, "Materias primas para la fabricación de soportes de baldosas cerámicas, $2^{\text {nd }}$ Ed., Instituto de Tecnología Cerámica (ITC)", Castellón (2002) 272-286. [28] ASTM C326 - 09, Standard Test Method for Drying and Firing Shrinkages of Ceramic Whiteware Clays, American Society for Testing and Materials, West Conshohocken, PA, USA(2009).

[29] J. García-Ten, Descomposición durante la cocción del carbonato cálcico contenido en el soporte crudo de los azulejos, Ph.D. Thesis, Universidad Jaume I, Castellón, Valencia, Spain(2005).

[30] ASTM C373 - 88,Standard Test Method for Water Absorption, Bulk Density, Apparent Porosity, and Apparent Specific Gravity of Fired Whiteware Products, American Society for Testing and Materials, West Conshohocken, PA, USA (2006).

[31] ASTM C674 - 88, Standard Test Methods for Flexural Properties of Ceramic Whiteware Materials", American Society for Testing and Materials, West Conshohocken, PA, USA (2006).

[32] G. Biffi, O gres porcelanato: manual de fabricação e técnicas de emprego, $3^{\text {rd }}$ Ed., Faenza Ed. do Brasil Ltda., S. Paulo, Brazil (2002).

[33] S.K. Das, K. Dana, "Differences in densification behaviour of $\mathrm{K}$ - and Na-feldspar-containing porcelain bodies", Thermochim. Acta. 406 (2003) 199-206.

[34] A. Guzmán, Utilización de ceniza de tamo de arroz como reemplazo del feldespato y del cuarzo en la elaboración de gres porcelánico, Ph.D. Thesis, Universidad del Valle, Cali, Valle, Colombia (2014).

(Rec. 01/06/2015, Ac. 23/07/2015) 